\title{
The Issues in Implementing Transition Program for Special Needs Students
}

\author{
Aliza Alias ${ }^{1}$ \\ ${ }^{1}$ Faculty of Education, Universiti Kebangsaan Malaysia, Selangor, Malaysia \\ Correspondence: Aliza Alias, Faculty of Education, Universiti Kebangsaan Malaysia, 43600 UKM Bangi, \\ Selangor, Malaysia. Tel: 60-3-8921-6273. E-mail: eliza@ukm.my
}

Received: August 16, 2013 Accepted: October 14, 2013 Online Published: November 28, 2013

doi:10.5539/ass.v9n16p9

URL: http://dx.doi.org/10.5539/ass.v9n16p9

\begin{abstract}
This study is to determine the challenges and barriers faced by the special education teachers in implementing transition program for special needs students in Malaysian secondary schools. The issues that will be discussed are obstacles to the success of planning, training and placing the special needs students in the real working environment from the teachers' perspective. The study found that these students posed attitude problems during training sessions, lacked commitment to attend training sessions and faced difficulties adjusting to working environment. Apart from that, the teachers agreed that finding workplaces for students with special needs to gain working experience outside the school and the employers' readiness to accept trainees with learning disabilities are two issues that are crucially in need to be dealt with wisely. Even though there are many issues in implementing the transition program, the teachers are still very dedicated not only in monitoring the students' progress but also in ensuring the well-being of the students at their working environment during internships.
\end{abstract}

Keywords: special needs students, transition, working experience

\section{Introduction}

Special needs students who are going to leave the formal educational system without any future plans seem to be the main concern for most parents. While other school peers will continue to pursue studies at post-secondary education or even venture into workforce, the special needs students might just end up at home, even though some of these students have basic learning skills and capable to be trained in acquiring some vocational skills. This scenario is also discussed by Lindstrom, Doren and Miesch (2011) as they claimed that these young adults often struggled with disability and other personal barriers, yet some of them can be transitioned into work force or postsecondary training.

Even though there are vocational education for special needs students in Malaysia, not all students have the opportunities to enroll in the program. In fact, there are three boarding vocational schools for special needs students in Malaysia. These schools are specially designed for the special needs students, with qualified teachers using adapted curriculum to suit the students' abilities and strengths to learn and acquire the skills needed. Only capable and qualified special needs students are offered to go to these boarding schools. Unfortunately, there are parents who are protective and refuse to let their children go as these schools are far from home. Besides that, there are also some local schools that provide vocational training for capable special needs students.

Even though the teachers for special needs students in secondary schools are usually aware of the transition program, but not all schools provide the opportunity for the students to be transitioned out to workplace after completing the training. The vocational training in schools only reflects the first part of the transition program; which is in giving knowledge and skills for the students to acquire. However, there are few internship placements for the students to gain working experience after they have finished the program. Consequently, the teachers' roles have become even more challenging as they have to cater not only to the special needs of the students to be trained but also finding willing employers to accept them for internship.

According to Shogren and Plotner (2012), a transition program is a coordinated set of activities for a special needs student, designed within an outcome-oriented process that promotes movement from school to out-of-school activities. The special needs students are given the opportunity to be assisted in acquiring skills needed for gaining working experiences. These processes are crucial in giving the students guidelines to be 
successful in transition from school to real life after finishing their schooling years (Etscheidt, 2006). The coordinated activities must be based on the students' needs, preferences and interests. The teachers should also identify specific areas of strengths and needs; develop instructional objectives and curricular materials; and design effective intervention efforts to increase appropriate behaviour and coping mechanism that are crucial in working environment (Carter, Lane, Pierson \& Glaeser 2006). Therefore, the activities in the transition program should cover functional academics, daily living skills, community experiences and functional vocational evaluation. The training of the skills needed, should be adaptable and suitable to the students' abilities and special needs (Leconte, 2006). The learning process and training for the special needs students should be based on the aim, vision and interest of the students.

Therefore, the implementation of transition programs should consider the students' abilities or potentials, interest and ability to complete the tasks given. However, finding suitable working placement for the students' internship could be a big challenge for the teachers. As McMillin \& Shuey (2006) had stated, disabled person in working sector has still not fully accepted by employers as they were not confident that these disabled would performed accordingly. They were afraid that there would be some problems if they hire disabled worker in their premises. They were also concern about the negative perceptions of their customers.

In Malaysia, there are no transition services and support teams in secondary schools. Most of the responsibilities in transition programs are held by special education teachers involved in the program. Therefore, most of the teachers from special education program run the transition program on their own initiatives. The responsibilities such as to identify the students' strengths, suitable jobs, challenges and strategies, develop action plan, follow up, develop vocational skills and experience through internship such as interviews, negotiation and placement (Nietupski, Warth, Winslow, Johnson, Douglas, Johnson \& Cilek 2006) were done by the teachers. Not only the teachers have to undertake various responsibilities in transition implementation but the parents also should take part in this program to help and support their children to succeed in the program especially during internships. Family supports and positive expectations are needed not only in preparing students for work placement, but also gaining work skills through school to-work transition (Lindstrom et al., 2011).

There are various factors that can impede the effectiveness of transition programs, but Lindstrom, Doren and Miesch (2011) found that working experiences, transition services and family supports and expectations, played critical roles in the success of transition from school to career development. The students must be given an opportunity to work during high school, in order to possess critical work skills and behaviour such as teamwork, responsibility and work ethics. The finding showed that the transition programs have improved the students' personal attributes - such as self-efficacy, motivation and coping skills. The study also found that the interns were highly motivated to work and basically developed general positive interaction in work places.

Therefore, the focus of transition programs should be on individual knowledge and skills, such as self-determination, self-advocacy and communication. The students need to know how to cope with the constant changes and demands of the work environment. Positive interactions with colleagues in the workplace can help establish valuable mentoring relationship and ultimately lead to career advancement (Lindstrom et al., 2011).

With positive effect of transition program on the students' personal attribute and working experiences, Yaeda and Jindal-Snape (2011) added that the students should be given opportunities to develop vocational skills at an early age as they are best learned in a real work setting. Moreover, both researchers believed that supported education, supported employment and life span development counselling are all good contributors for successful transition from school to work for students with disabilities. This is supported by Crudden (2012) who had listed the components for success in transition to employment which are early transition, problem solving skills, social skills, employment-related skills and, interest and communication skills.

\section{Objective}

The objective of this study is to identify the issues faced by the special education teachers in implementing transition programs in secondary schools for special needs students from school to work.

\section{Methodology}

This study is based on 4 teachers' experiences from different secondary schools, in implementing transition program at their respective schools. The teachers were interviewed and also asked to write a report on the transition program. Teacher A and Teacher B have been teaching special education class for more than 7 years while Teacher $\mathrm{C}$ and Teacher $\mathrm{D}$ have less than 5 years of teaching experiences. Teacher A and Teacher B were also involved in prevocational training program for special needs students in their schools. The special education program in Teacher A's school, has an entrepreneur project in making and selling burger during recess time. 
While Teacher B was involved in sewing class for special needs students at her school. Since both programs only trained the students, therefore both Teacher A and Teacher B were asked to select a student each to be transitioned from school to working environment outside the school setting. The teachers have to find willing employers to take in the chosen students as their interns with the consent from the students' parents. The teachers also have to prepare the students emotionally and socially before they could be placed at the new working environment.

On the other hand, Teacher $\mathrm{C}$ and Teacher D were asked to identify and train a student each for the transition program, as their schools do not provide vocational program. Two students were selected based on their capabilities to function in real working situation. Students $\mathrm{C}$ was trained to make drinks and other related skills needed at an eatery stall while Student D was trained to acquire skills needed in a laundry shop. Before the training and placement of the internships, both teachers have to get the parents' permission and explain the aim of the transition program. The teachers also managed to get the permission from the school administration to train the students during class hours. The period of the training were varied for each student depending on the consent from the school administration and students' abilities to acquire the skills needed. At the end of the training, the students were sent to gain working experience at their respective working places.

\section{Findings}

All the teachers involved in this study were very committed in giving their best to their students' success in gaining working experiences. All the teachers managed to find a place for the trained students to do their short internships. The 3 male students who were 17 years old, were placed at a burger stall (Student A), a tailor shop (Student B) and an eatery stall at a fishing pond (Student C). While the only 15 year-old female student (Student D) was accepted to work at a laundry shop. All the students can read and write with basic arithmetic skills.

From the interviews and the reports on the progress of the students involved, it is found that all the teachers faced with same issue that make it difficult for the success of transition from school setting to working environment.

\subsection{Training the Students}

In planning the transition program, the teachers need to consider the students' abilities, strength and interest. Therefore, the teachers had to identify students who are capable to be trained and could acquire the skills needed in a specific period of time. Identifying students to be a part of transition program was a difficult process. Basically the students were chosen based on their level of achievement in writing, reading and arithmetic. However, their learning disabilities and inability to function socially might affect the transition process. Therefore, the students have to be carefully chosen to ensure that they were capable to function outside their comfort zone. They should also be able to adapt emotionally and socially to their respective working environments.

All the teachers agreed that training the students is a challenge, as some of the students' attitudes could affect the students' survival during their internship. Attitudes such as easily get bored, difficult to focus on the task given and sometimes do not really understand the instructions given, have to be attended by the teachers wisely or the students might quit the program or discontinue the program. So, apart from training the students the skills needed, the teachers also have to educate and prepare the students with ethics and rules in working environment, so they would be ready for the internships. All the male students were looking forward to work and earn some money. Whereas Student D was a little bit reluctant at first, but she gave in after much persuasion not only from the teacher but also from her family.

\subsection{Internships and Employer's Readiness}

Another big challenge for the teachers was to find a place for the students to practice their skills and gain working experiences outside the school setting. This is the main challenge for the teachers in implementing transition program. The teachers had to approach several outlets or employers before finally they managed to secure a job for the students related to their skills. Almost all the employers approached, were reluctant to accept special needs person working at their premises. Fortunately, four employers agreed to take in the students and help them to gain working experiences. Even though, at first they had doubt about hiring these students to work at their premises, but after the teachers explained about the students' abilities and skills, the employers decided to give it a try. But before the students were accepted, they were interviewed and asked to demonstrate some of the skills needed.

Employers for Student A, B and C were very helpful and open minded after they were given a clear objective of the program. On the other hand, Employer D was very sceptical and reluctant to have Student D to work at her 
laundry shop. She was afraid that her customers might be uncomfortable being attended by a learning disabled girl who was slightly physical handicapped. But Teacher D continuingly persuaded and assured that Student D was trained and capable to do the job. Finally with the support from her husband, the laundry lady gave in and accepted Student D with several conditions. It was a relief for Teacher D, even though Student D can only work for 4 weeks from 2-5 pm every Monday to Friday. At first, Teacher D was very frustrated with several rejections but her determination had won the trust of the Employer D's husband to secure a work place for her student's internship.

Similarly, Teacher B and C also experienced several rejections after they informed the future employers that the students have learning disabilities. Teacher $\mathrm{C}$ had approached and contacted 5 tailors and only two tailors were willing to take the student as an intern. She had problems in convincing the future employers about the student's abilities and skills in sewing. Some of the comments she got from 3 tailors near the student's home:

...Can the student work. not really confident.

...I can take him, but I do not know how to teach him.. and I have no patient if he could not get it after being taught several times.

Can he use the sewing machine?

Unfortunately the two tailors who were willing to take in Student C and teach him other sewing skills were far from the student's home.

Therefore, it was a frustrating experience for the teachers in finding willing employers to accept special needs trainees to do internship at their premises even for a short period of time. It is definitely a huge barrier to the success of transition program especially getting a job that is located near the students' home so that it is easy for them to commute to their work places.

\subsection{Adjustment to Working Environment}

At first, all the students have problems in adjusting to the routine and climate of their new working environment. The students were facing difficulties to adapt to the working environments. All the teachers except Teacher B had to be at the premises for the whole first week during the internship to monitor the students' progress of adaptation into working environment. Teacher B was confident that Student B would be able to adapt to his working environment which was $130 \mathrm{~km}$ away from home. So, Teacher B had made arrangement for Student B's accommodation throughout the internship. After Teacher B was satisfied that student's B well-being had been attended to, she left 3 days later. But she kept in touch with Student B and called regularly the employer to check on the student's progress throughout the internship.

Meanwhile, Student A and Student C have problems in understanding instructions and customers' orders. So the teachers had explained to the employers that the students have problems getting the order correctly if there were many customers at one time. After a while, the students were adjusting smoothly throughout their internships. All the three male students were paid during their internships and they were offered to continue working after their internships ended.

Whereas, student $\mathrm{D}$ was given a small token of appreciation after she finished her internship even though in the beginning she couldn't work independently. Employer D commented that Student D had attitude issue that need to be resolved in order to survive in working environment. The student also need more time to be efficient in completing the tasks given. As Student D was 15 years old, she still has plenty of time to improve her attitude problems. Some of the attitudes pointed out by Employer D:

...impatient in completing task given

...sulking when I point out she was not folding correctly

...repeating the same mistake...

Surprisingly, after 2 weeks the employer decided to trust Student D to attend customers at the counter, receiving dirty laundry and checking out clean laundry without any supervision. Feedbacks from the customers were very positive as they were impressed to see a special needs girl working at the laundry shop. Consequently, given sufficient time, all the students were able to adapt to their respective working environment and enjoy working throughout the internships.

\section{Discussions}

This study offered perspectives into transition process for special needs students who were successfully gained working experiences outside their learning environments. The process of identifying the students was based on 
interest and capabilities to be trained for the transition program as suggested by Leconte (2006). The teachers also considered the possibilities of the students to function emotionally and socially during the school-to-work transition. All three male students were employed and continued working with their respective employers, as the students had gained trust and respect from their employers. In addition, the only female student was highly motivated and she even wanted to continue working even though the term of internship had ended. This reflects the impact of the transition program as it has improved the students' self-confident. The program also has educated prospective employers that special needs students are able to function if they are given suitable training program and a chance to gain working experience in real workplaces as supported by findings from Lindstrom et al. (2011). The changes in the students' attitudes, especially increased confidence in social interactions has gained the parents' assistance and supports in assuring the success of the transition process from school to workplace. Furthermore, the parents were relief and grateful that their children were capable to work and earn some money if they were trained for the job.

Moreover, the success of the transition program would also rely on the support from the school administration. The schools should support the program by providing the necessary tools, materials and also a place for the training session. However, the most challenging issue the teachers have to deal with is to find a place for their students' internships in order to gain working experiences; as working experiences will expose the students and prepare them for the real working world, and give them more opportunities to be employed (Lindstrom et al., 2011). The teachers have showed undivided commitments to train the students and find suitable working environment even though they were rejected several times. The teachers believed that working experiences were the key element of the success transition from school to workforce after the students acquired not only the vocational skills but also social and emotional skills to function in the working environment. Furthermore, the teachers were grateful and appreciated the parents' supports in believing in their children's capabilities to function in workforce and the employers' readiness to accept and help the trained special needs students to gain working experiences.

\section{Conclusion}

The commitment of special education teachers in implementing the transition program from school to working environment is the real element of this program's success. The teachers are very dedicated and diligently resolving the barriers faced and took it as challenges to improve the program. Their awareness of the needs for students with learning disabilities to be trained and exposed to the working experiences outside the school setting is crucial in the planning and implementation of the transition program; as they believed the program has helped the special needs students to gain working experiences that would be useful for the students in the working world after leaving school. Therefore, the teachers' determination to address the issue in implementing the transition program should be shared and supported not only from the school administration and parents but also from prospective and potential employers in training and preparing these special needs students to venture confidently and bravely into the working world.

\section{References}

Brolin, D. E., \& Lyod, R. J. (2004). Career Development and transition services: A functional life skills approach (4th ed.). USA: Pearson Prentice Hall.

Carter, E. W., Lane, K. L., Pierson, M. R., \& Glaeser, B. (2006). Self-determination skills and opportunities of transition-age youth with emotional disturbance and learning disabilities. Exceptional Children, 72(3), 333-346.

Cruden, A. (2012). Transition to employment for students with visual impairments: Components for Success. Journal of Visual Impairment \& Blind, 106(7), 389-399.

Etscheidt, S. (2006). Issues in transition Planning: Legal Decisions. Career Development for Exceptional Individual, 29(1), 5-14.

Leconte, P. J. (2006). The evolution of career, vocational and transition assessment: Implications for the summary of performance. Career Development for Exceptional Individuals, 29(2), 114-124. http://dx.doi.org/10.1177/08857288060290020301

Lindstrom, L., Doren, B., \& Miesch, J. (2011). Waging a living: Career development and long-term employment outcomes for young adults with disabilities. Exceptional Children, 77(4), 423-434.

Loyd, R. J., Cook, I. D., Opperman, C., \& Thurman-Urbanic, M. (2004). Transition planning. In D. E. Brolin, \& R. J. Lyod, (Eds.), Career Development and transition services: A functional life skills approach. (pp. 195-220). USA: Pearson Prentice Hall. 
McMullin, J. A., \& Shuey, M. K. (2006). Ageing, disability and work place accommodations. Ageing and Society, 26, 831-847. http://dx.doi.org/10.1017/S0144686X06004958

Nietupski, J., Warth, J., Winslow, A., Johson, R., Douglas, B., Johson, M., \& Cilek, J. (2006). Iowa’s High School super senior school-to-work transition program. The journal for Vocational Special Needs education, 29(1), 17-29

Shogren, K. A., \& Plotner, A. J. (2012). Transition planning for students with intellectual disability, autism, or other disabilities: Data the national longitudinal transition study-2. Intellectual and Development Disabilities, 50(1), 16-30. http://dx.doi.org/10.1352/1934-9556-50.1.16

Yaeda, J., \& Jindal-Snape, D. (2011). Post-school transition of students with disabilities: The Japanese experience. International Journal of Humanities and Social Science, 9(17), 112-117.

\section{Copyrights}

Copyright for this article is retained by the author(s), with first publication rights granted to the journal.

This is an open-access article distributed under the terms and conditions of the Creative Commons Attribution license (http://creativecommons.org/licenses/by/3.0/). 